\title{
MENINGKATKAN HASIL BELAJAR MATEMATIKA MATERI KECEPATAN MENGGUNAKAN MODEL COOPERATIVE TIPE GRUP INVESTIGATION KELAS VB MI NW KALIJAGA.
}

\author{
Ulfa Nurhakikah ${ }^{1}$ Hayaturraiyan ${ }^{2}$ \\ ${ }^{1}$ STAI Darul Kamal NW Kembang Kerang. Jl. Parawisata Kembang Kerang Lotim NTB \\ ${ }^{2}$ Dosen STAI Darul Kamal NW Kembang Kerang, Jl. Parawisata Kembang Kerang Lotim NTB \\ *Author:1hakikabalfi@gmail.com²hayat.raiyan@gmail.com
}

\begin{abstract}
Abstrak
Penelitian ini dilakukan untuk meningkatkan hasil belajar siswa pada mata pelajaran Matematika materi kecepatan menggunakan model Cooperative Tipe Grup Investigationdi kelas VB MI NW Kalijaga. Jenis penelitian ini yaitu Penelitian Tindakan Kelas (PTK) dengan menggunakan metode kuantitatif, karena data ini menggunakan angka, mulai dari pengumpulan data, penafsiran data dan penampilan hasil.Subjek penelitian adalah siswa kelas V MI NW Kalijaga dan sampel sampel penelitian kelas VB MI NW Kalijaga sebanyak 14 siswa.Hasil penelitian ini terlihat dari hasil belajar siswa, pada prasiklus masih banyaknya siswa yang belum tuntas berdasarkan KBM (73\%), pada pra siklus hanya ada lima siswa yang tuntas $(35,7 \%)$ dengan nilai rata - rata 56,8, nilai tertinggi 93 dan nilai terendah 30.Pada siklus satu ada peningkatan menjadi tujuh orang siswa siswa (50\%) yang tuntas $\mathrm{KBM}$, nilai rata-rata 63,2 , nilai tertinggi 95 dan nilai terendah 30. Pada perbaikan pembelajaran siklus dua dari 14 siswa yang tuntas KBM meningkat lagi menjadi 10 siswa (89\%), nilai rata-rata 75,6, nilai tertinggi 98 dan nilai terendah 40 .
\end{abstract}

Kata kunci : Hasil Belajar, Group Investigation, kecepatan.

\section{PENDAHULUAN}

Pembelajaran matematika merupakan mata pelajaran yang selalu di anggap sulit dan menjadi momok bagi sebagian besar peserta didik. Hal ini disebabkan dikarenakan pelajaran matematika merupakan mata pelajaran yang mempunyai karakteristik khusus, antara lain abstrak ${ }^{1}$, deduktif $^{2}$, dan logis ${ }^{3}$. Keabstrakan pelajaran matematika disebabkan karena objek dasarnya abstrak yaitu fakta, konsep, operasi, dan memiliki prinsip. Karena sifat inilah yang menjadikan mata pelajaran matematika sulit untuk di pahami, namun bukan berarti merupakan mata pelajaran yang sulit untuk dipelajari.Padahal sekarang ini tidak dapat dipungkiri bahwa eksistensi pembelajaran matematika sangat berpengaruh terhadap kemajuan IPTEK/ilmu pengetahuan dan teknologi. Hal itu disebabkan mata pelajaran matematika berguna dan dibutuhkan dalam semua aspek kehidupan manusia, sehingga penulis sebagai calon pendidik berusaha membuat siswa mau belajar dan menyukai mata pelajaran matematika.

Dalam kamus besar bahasa Indonesia, secara etimologis belajar memiliki arti "berusaha memperoleh kepandaian atau ilmu"4. Belajar adalah suatu proses perubahan tingkah laku pada siswa akibat adanya interaksi antara individu dan lingkungannya melalui proses pengalaman dan

\footnotetext{
1 Abstrak berrti sesuatu yang tidak berwujud; tidak berbentuk; mujarad; niskala:

2 Deduktif berkenaan dengan sesuatu yang bersifat Edukasi.

3 Logis berkenaan dengan kesesuaian dengan logika manusia; benar menurut penalaran dan masuk akal

4 Team Pustaka Phonix, Kamus Besar Bahasa Indonesia, (Cet. Iii; Jakarta: Pt. Media Pustaka Phonix, 2008), Hlm
} 121. 
latihan. ${ }^{5}$ Oleh karena itu, pembelajaran di sekolah harus diciptakan dengan suasana yang kondusif dan menyenangkan agar tercapai segala tujuan pembelajaran yang telah ditetapkan. ${ }^{6}$

Realitas yang terjadi di MI NW kalijaga, khususnya kelas V B adalah masih rendahnya semangat siswa dalam belajar matematika, terutama di bagian materi kecepatan sehingga hal tersebut mengakibatkan rendah hasil belajar yang dicapai siswa. Secara keseluruhan siswa kurang bersemangat untuk menguasai suatu konsep, khususnya materi kecepatan, hal ini dibuktikan dengan banyaknya siswa yang tidak berani bertanya ataupun menjawab pertanyaan saat pelajaran berlangsung, dan nilai ulangan yang belum mencapai KBM (Ketuntasan Belajar Minimum).

Materi tentang kecepatan kurang menarik bagi siswa, karena kegiatan pembelajaran dilakukan dengan metode yang masih tradisional, ceramah dan mencatat sehingga siswa kurang menguasai konsep pembelajaran yang sebenarnya. Sehingga pembelajaran yang diperoleh siswa tidak berkesan dan kurang terserap maksimal. Hal ini dibuktikan dari hasil analisis nilai ulangan harian pada bulan Oktober 2021 menunjukkan hasil yang kurang maksimal yaitu banyak siswa yang belum mencapai KBM. Hal ini dapat dilihat dari nilai rata-rata yang dicapai kelas V B yang tuntas dari KBM dari jumlah siswa 14 anak, dengan perincian tuntas ada lima anak $(35,7 \%)$ dan tidak tuntas ada sembilan anak (64,3\%) dengan nilai tertinggi 80 dan nilai terendah 30 (dengan KBM $73 \%)$.

Masalah yang muncul tersebut disebabkan karena pemilihan metode dan model pembelajaran yang kurang tepat. Sehingga menyebabkan kurang menarik minat dan perhatian siswa. Guru tidak memberi kesempatan kepada siswa untuk menyampaikan rasa ingin tahunya dan siswa kurang diberi kesempatan untuk berpikir kritis serta proses pembelajaran hanya bersifat tradisional. Kegiatan dan proses pembelajaran monoton sehingga kurang berkesan,tidak bermakna bagi siswa, siswa tidak bersemangat, siswa memiliki rasa ingin tau yang rendah, kegiatan pembelajaran didominasi oleh guru sehingga hasil belajarnya cukup rendah.

Berdasarkan keadaan di atas, Menindak lanjuti rendahnya hasil belajar siswa yang berada dibawah KBM, maka guru berniat untuk melakukan kegiatan perbaikan pada proses pembelajaran agar siswa memiliki rasa tertarik terhadap materi kecepatan agar lebih berhasil. Dalam hal ini pembelajaran dengan penelitian langsung untuk membuktikan sesuatu berkaitan dengan materi agar bermakna dan menarik bagi siswa. Penggunaan model pembelajaran kooperatif akan lebih mengutamkan komunikasi dan kebersamaan antar siswa.

Cooperative learning merupakan suatu strategi pembelajaran yang menekankan aktivitas bersama para peserta didik dalam belajar yang berbentuk kelompok kecil, untuk mencapai tujuan yang sama dengan menggunakan berbagai macam aktivitas belajar guna meningkatkan kemampuan peserta didik dalam memahami materi pelajaran dan memecahkan masalah secara kolektif. ${ }^{7}$

Menurut Trianto terdapat beberapa tipe dalam model pembelajaran kooperatif antara lain STAD, jigsaw, investigasi kelompok (Group Investigation), teams games tournaments, think pair share, dan numbered head together. ${ }^{8}$ Group Investigation merupakan salah satu bentuk model pembelajaran kooperatif yang menekankan pada partisipasi dan aktivitas siswa untuk mencari

\footnotetext{
${ }^{5}$ M. Subana, Strategi Belajar Mengajar Bahasa Indonesia, ( Bandung; Pustakan Setia), Hlm 9.

6 Nimas Cantik Laraswati. Peningkatan Hasil Belajar Matematika Dengan Model Pembelajaran Group Investigation Pada Siswa Kelas Iii Sd Negeri 3 Kalikotes”. ( Klaten: 2019/2020) Hlm 1

7 Slavin, E. Robert. 2005. Cooperative learning:Theory, research and practice. Londong:Allymand Bacon. Hlm 10

8Trianto. 2011. Model Pembelajaran Terpadu Dalam Teori Dan Praktek. Jakarta: Prestasi Pustaka Publisher. Hlm 67
} 
sendiri materi (informasi) pelajaran yang akan dipelajari melalui bahan-bahan yang tersedia. Aktivitas siswa dalam proses pembelajaran sangat mempengaruhi hasil belajar, karena melalui aktivitas kita bisa mendapatkan hasil pembelajaran.

Adapun perbaikan pembelajaran yang penulis lakukan melalui Penelitian Tindakan Kelas (PTK) pada Mata Pelajaran Matematika secara khusus bertujuan: a) Mendiskripsikan cara yang efektif dalam pembelajaran matematika tentang berbagai latihan siswa mampu menyelesaikan masalah yang berkaitan dengan suatu besaran ( kecepatan) dengan model pembelajaran Group Investigation. b) Meningkatkan hasil belajar siswa berbagai latihan siswa mampu menyelesaikan masalah yang berkaitan dengan suatu besaran ( kecepatan) dengan model pembelajaran Group Investigation. c) Membangkitkan motivasi siswa untukpelajaran matematika tentangberbagai latihan siswa mampu menyelesaikan masalah yang berkaitan dengan suatu besaran ( kecepatan) model pembelajaran Group Investigation.

Penelitian yang serupa dengan menggunakan model kooperatif tipe Group Investigation juga pernah dialakukan oleh Iswahyudi Joko Suprayitno dan Solichatun dengan judul "Upaya Meningkatkan Hasil Belajar Matematika Menggunakan Model Group Investigation Materi Debit Air Siswa Kelas VI Zakariya SD Muhammadiyah Sukorejo Tahun 2016”. Dari penelitian yang terdiri dua siklus ini, berhasil dan dapat meningkatkan siklus I (75\%) dan siklus II (89\%).

Berdasarkan analisis tersebut di atas, peneliti tertarik juga untuk mengadakan penelitian dalam pembelajaran matematika di kelas V B menggunakan model pembelajaran GI, agar siswa dapat aktif dan memberi pengalaman secara langsung dalam menemukan materi pembelajaran. Berdasarkan permasalahan diatas, dalam penelitian ini penulis memilih Judul 'Meningkatkan Hasil Belajar Matematika Materi Kecepatan Menggunakan Model Cooperative Tipe Grup Investigation Kelas VB MI NW Kalijaga”.

\section{METODE}

Jenis penelitian ini adalah penelitian Penelitian Tindakan Kelas (PTK) yang dilakukan secara kolaborasi antara peneliti, guru matematika, dan kepala sekolah. Penelitian ini digunakan untuk meningkatkan hasil pembelajaran matematika khususnya materi kecepatan siswa kelas VB MI NW Kalijaga Kecematan Aikmel. Subjek dalam penelitianini yaitu: siswa kelas V B dengan jumlah berjumlah 14 anak yang terdiri dari delapan anak laki-laki dan enam anak perempuan.

Kegiatan penelitian berangkat dari permasalahan riil yang dihadapi oleh praktisi pendidikan dalam tugas pokok dan fungsinya masing-masing, kemudian direfleksikan alternatif pemecahan masalahnya dan ditindak lanjuti dengan tindakan-tindakan nyata yang terencana dan terukur. ${ }^{9}$

Model Penelitian yang digunakan oleh peneliti adalah jenis Penelitian Tindakan Kelas (PTK), dalam bahasa inggrisnya diartikan dengan Classroom Action Research. Pengertian dari PTK menurut Nana Saodih adalah proses memberikan kepercayaan kepada seorang pengembang kekuatan untuk dapat berfikir reflektif, berdiskusi, atau tindakan dari orang biasa yang ikut berpartisipasi dalam penelitian untuk mengatasi kesulitan yang dihadapi di dalam kelas. ${ }^{10}$

PTK ini menggunakan analisis deskripitif kuantitatif, karena penelitian ini menggunakan data berupa angka, mulai dari pengumpulan data, penafsiran data tersebut serta penampilan dari hasilnya. Hasil belajar siswa yang belum mencapai KBM, membuat peneliti ingin

9 Sutama. 2007. "Model Pembelajaran Kooperatif Tipe Group Investigation Untuk Pengembangan Kreativitas Mahasiswa". Varidika/Vol. 19, No. 1, Pp. 1-14.

${ }^{10}$ Nana Saodih Sukmadinata, Metode Penelitian Pendidikan, (Bandung: Remaja Rosdakarya, 2017), hlm. 142. 
memperbaiki proses kegiatan pembelajaran. Dengan diperbaikinya proses pembelajaran, diharapkan siswa dapat mencapai hasil di atas KBM yang ditentukan oleh guru.

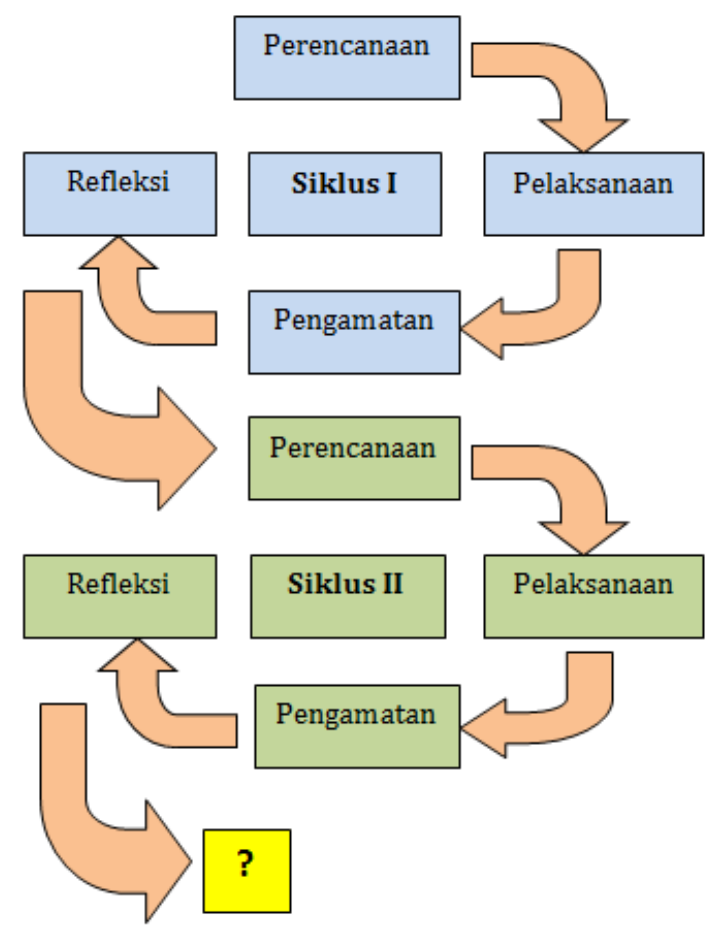

\section{Gambar 1. Siklus Penelitian Tindakan Kelas (PTK). ${ }^{11}$}

Beberapa ahli berpendapat tentang model penelitian tindakan yang secara garis besar terdapat empat tahapan, yaitu (1) perencanaan, (2) pelaksanaan, (3) pengamatan, dan (4) refleksi. Keempat tahap ini adalah unsur untuk membentuk sebuah siklus, yaitu satu putaran kegiatan beruntun, yang kembali kelangkah semula. Jadi, bentuk penelitian tindakan ini tidak pernah merupakan kegiatan tunggal, tetapi rangkaian kegiatan akan kembali ke asal, yaitu dalam bentuk siklus. Berdasarkan hasil dari tes awal, penelitian ini didesain menjadi dua siklus. Setiap tindakan dalam satu siklus saling berhubungan. Tindakan siklus I berdasarkan refleksi. Pra siklus tindakan siklus II berdasarkan hasil refleksi siklus I. Tiap-tiap siklus 3 jam pelajaran $(3 \times 35$ menit).

\section{Pelaksanaan Siklus I}

1. Tahap Perencanaan (Planning) dilakukan pengamatan awal terhadap situasi kelas dalam konteks situasi sekolah secara umum. Di lanjutkan memebuat perangkat pembelajaran : membuat program tahunan (PROTA), membuat program semester (PROMES), mengembangkan silabus, membuat Rencana Perangkat Pembelajaran (RPP), rencana penelitian, sistem penelitian, lembar Observasi dan instrumen penelitian.

2. Tahap Pelaksanaan (Acting)

a. Kegiatan awal

1) Kelas dimulai dengan Salam, menanyakan kabar dan mengecek kehadiran siswa.

11 Arham syahban(2020), Pendidikan Jasmani dan Rohani, di akses di https://www.arhamsyahban.com/2020/04/ptk-pendidikan-jasmani.html pada hari rabu, 10 november 2021 
2) Kelas dilanjutkan dengan do'a dipimpin oleh guru.

3) Guru mengabsen siswa..

4) Guru mengulas kembali materi yang disampaikan sebelumnya

5) Menyampaikan tujuan pembelajaran hari ini.

6) Guru mengarahkan kegiatan pembelajaran akan di laksanakan di luar ruangan (OutDoor).

b. Kegiatan Inti

1) Siswa mendengar dan guru menjelaskan tentang tahap-tahap Grup Investigation

2) Masing-masing kelompok diberikan Lembar Kerja/ Lembar Observasi. Lalu mengamatinya bersama anggota kelompoknya.

3) Guru memberikan kesempatan kepada siswa untuk bertanya tentang kegiatan yang akan dilaksanakan.

4) Guru menjelasakan pertanyaan siswa.

5) Siswa mencoba berdiskusi dengan temannya tentang menghitug kecepatan berlari

6) Guru menunjuk semua ketua kelompok untuk menemani guru mengukur keliling lapangan, sambil mencatat panjangnya.

7) Guru memberikan pembenaran dan masukan apabila terdapat kesalahan atau kekurangan pada siswa dalam penghitungan. (Creativity and Innovation)

8) Guru memberikan kesempatan kepada siswa untuk mementukan 3 pelari dalam observasi.

9) Guru meminta siswa untuk menulis waktu tempuh setiap anggota kelompok yang berlari di lembar kerja.

10) Guru menunjuk beberapa siswa untuk menuliskan hasil pekerjaanya dan menghitung kecepatan lari setiap anggota. Critical Thinking and Problem Formulation)

11) Siswa mempresentasikan secara lisan kepada teman-temanya tentang menghitug kecepatan lari anggota kelompoknya.

12) Siswa menyampaikan manfaat belajar menghitug kecepatan suatu benda yang dilakukan secara lisan di depan teman dan guru. (Communication)

c. Penutup

1) Guru memberikan penguatan materi dan kesimpulan.

2) Guru mengapresiasi hasil kerja siswa dan memberikan motivasi

3) Guru menyampaikan pesan moral hari ini dengan bijak

4) Salam dan do'a penutup. ${ }^{12}$

3. Tahap Pengamatan(Observing)

Observasi ini dilakukan bersama teman sejawat, guru pamong dan DPL, di dalam melaksanakan observasi yang paling dikedepanakan adalah aktivitas dan hasil belajar dalam setiap proses pembelajaran berlangsung. Observing yang berlangsung di upayakan seminimal mungkin tetap berjalan sesuai dengan Planning.

4. Tahap Refleksi (Reflection) Dalam tahap ini peneliti mengkaji, melihat dan mempertimbangkan dampak dari tindakan yang telah dilakukan pada pra siklus dan siklus I. Hasil yang diperoleh pada tahap observasi dan hasil tes disimpulkan dan dianalisis pada tahap ini. Dari hasil yang didapatkan dijadikan bahan acuan untuk merencanakan siklus II sehingga yang dicapai pada siklus berikutnya sesuai dengan yang diharapkan dan bisa lebih

12 Rpp Siklus I Materi Kecepatan 
baik dari siklus $I .{ }^{13}$ Adapun untuk menentukan ketuntasan hasil belajar klasikal dapat dihitung dengan menggunakan rumus :

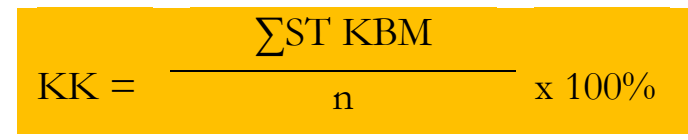

Keterangan: $\quad \mathrm{KK}=$ Ketuntasan Klasikal

$\sum \mathrm{ST}=$ Jumlah Siswa yang Tuntas KBM

$\mathrm{KBM}=$ Ketuntasan Belajar Minimum (73\%)

Berdasarkan hasil dari teknik analisis data, maka peneliti menentukan penelitian dianggap berhasil apabila hasil belajar peserta didik telah mencapai $\geq 73 \%$ khussnya dalam materi jarak, waktu, dan kecepatan adalah $73 \%$ ketuntasan klasikal (KK) menggunakan rumus rata-rata seperti yang dicantumkan di atas.

Sedangkan tehnik analisis data yang dilakukan dalam penelitian ini adalah deskriptif kuantitatif. Analisis deskriptif kuantitatif untuk mengolah data nilai yang berupa kemampuan hasil belajar matematika yang dianalisis dengan pencapaian persentase. Hal ini dimaksudkan siswa akan mampu dikatan menguasai materi jika persentase ketuntasan mencapai KBM yaitu 73\%. Teknik pengumpulan data kuantitatif dengan cara melakukan tes tertulis yang berupa ulangan harian dan LKPD ( Lembar Kerja Peserta Didik ) di lapangan.

\section{Hasil Penelitian dan Pembahasan}

Penelitian Tindakan Kelas yang di laksanakan di MI NW Kalijaga kelas V B menggunakan Model Cooperative Tipe Grup Investigation ternyata memberi perubahan bagi proses pembelajaran peserta didik khususnya matapelajaran Matematika materi kecepatan, perubahan yang paling nampak terlihat yaitu pembelajaran kemlompok membuat proses pembelajran lebih efektif, kerjasama kelompok dalam pembelajaran ini dapat membangkitkan semangat siswa untuk memiliki keberanian dalam mengemukakan pendapat dan berbagi informasi dengan teman lainnya dalam membahas materi pembelajaran. Adapaun hasil penelitian yang menggunakan analisis kuantitatif sebagai berikut :

Tabel 1. Data hasil Pre Test, Siklus I dan Siklus II

\begin{tabular}{|c|c|c|c|c|}
\hline NO & Nama Siswa & Pre Test & Siklus I & Siklus II \\
\hline 1. & A1 & 75 & 85 & 95 \\
\hline 2. & A2 & 65 & 75 & 80 \\
\hline 3. & A3 & 40 & 50 & 75 \\
\hline 4. & A4 & 40 & 30 & 40 \\
\hline 5. & A5 & 75 & 95 & 98 \\
\hline 6. & A6 & 80 & 85 & 95 \\
\hline 7. & A7 & 30 & 35 & 40 \\
\hline 8. & A8 & 40 & 40 & 50 \\
\hline 9. & A9 & 75 & 80 & 95 \\
\hline
\end{tabular}

${ }^{13}$ Munira M. Penerapan Model Pembelajaran Kooperatif TipeGroup Investigation (Gi) Dalam Meningkatkan Hasil Belajar Matematika Siswa Kelas XI Ipa 2 SMA PMDS Putri Palopo. ( Palopo : 2017) Hlm 59 


\begin{tabular}{|r|c|c|c|c|}
\hline 10. & A10 & 30 & 30 & 75 \\
\hline 11. & A11 & 30 & 40 & 60 \\
\hline 12. & A12 & 70 & 75 & 85 \\
\hline 13. & A13 & 70 & 70 & 75 \\
\hline 14. & A14 & 75 & 95 & 95 \\
\hline \multicolumn{2}{r|r|}{ Jumlah } & 795 & 885 & 1058 \\
\hline \multicolumn{2}{r|}{ Nilai Rata-Rata } & $56,8 \%$ & $63,2 \%$ & $75,6 \%$ \\
\hline \multicolumn{2}{r|}{ Ketuntasan $(\%)$} & $35,7 \%$ & $50 \%$ & $89 \% \%$ \\
\hline
\end{tabular}

\section{Pra Tindakan (Pra Siklus)}

Sebelum mulai melaksanakan penelitian pada siklus I, terlebih dahulu melaksanakan pra tindakan, penelitian ini bertujuan untuk mengetahui data awal nilai mata pelajaran matematika siswa kelas V B MI NW Kalijaga sebelum dilaksanakannya proses tindakan.dalam pengamatan tersebut penulis menemukan beberapa problem dalam kreatifitas pembelajaran diantaranya penulis melihat peserta didik lebih banyak bermain atau mengikuti pembelajarn secara tidak serius, belum lagi pada saat proses kegiatan inti berlangsung tidak sedikit peserta didik yang bereperan aktif saat berdiskusi dengan guru, bahkan banyak pula yang bingung terhadap apa yang mesti didiskusikan pada saat itu.hal ini menunjukkan kurangnya tingkat antusias belajar peserta didik yang tentunya berimplikasi pada nilai atau hasil belajar mereka.

Dalam kegiatan Prasiklus peneliti hanya menggunakan metode ceramah dan tanya jawab, belum menggunakan model Cooperative Tipe Group Investigation. Adapun nilai dari hasil evaluasi pra tindakan sebagai data awal yang peneliti laksanakan pada hari Kamis, 21 Oktober 2021 pada jam pelajaran pertama, kedua dan ketiga atau dimulai dari jam 07:30 sampai pukul 09:15 WITA dengan alokasi waktu 3 x 35 menit dapat didistribusikan ke dalam rentangan nilai sebagai berikut:

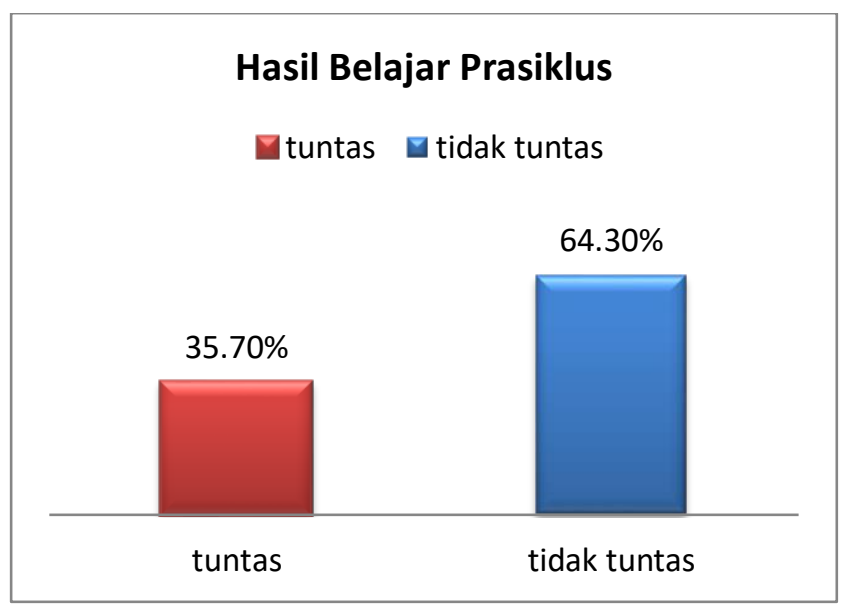

\section{Grafik 1. Persentase Hasil Belajar Siswa pada Prasiklus}

Berdasarkan tabel dan grafik diatas dapat dianalisis sebagai berikut:

a. Pada pra tindakan yang telah mencapai kriteria keberhasilan yaitu baru 5 siswa $(35,7 \%)$, yaitu nilai sama atau lebih dari KBM 73\%.

b. Pada pra tindakan terdapat 9 siswa $(64,3 \%)$ yang belum mencapai kriteria keberhasilan, yaitu nilai belum sesuai dengan KBM $73 \%$. 


\section{Hasil Siklus I}

Pelaksanaan tindakan pada siklus I dilaksanakan pada hari Kamis, 28 Oktober 2021, pukul 07:30 sampai 09:15 WITA, Sebelum melakukan tindakan peneliti terlebih dahulu mempersiapkan rencana pelaksanaan pembelajaran (RPP) dan Lembar Kerja Peserta Didik (LKPD) untuk satu kali pertemuan yaitu 3 x 35 menit. Materi pada siklus ini adalah kecepatan.

Pada kegiatan inti pembelajaran peneliti memebentuk empat kelompok yang masingmasing kelompak ada yang terdiri dari 3 orang dan 4 orang. Setiap kelompok menentukan pelari dan satu orang memegang stopwach, tahap berikutnya masing-masing ketua kelompok menghitung keliling lapangan dilanjutkan dengan menulis timeing dan kecepatan berlari masing-masing anggota yang diutus oleh kelompoknya, setelah itu hasil kecepatan berlari darimasing-masing utusan dicatat di Lembar Observasi LKPD. Setelah selesai lomba lari di lapangan, lalu peneliti mengumpulkan nilai kecepatan berlari dalam LKPD untuk dijadikan soal tes siklus I.Tahap tes ini dilakukan untuk mengetahui seberapa jauh pengetahuan mereka tentang materi kecepatan.

Pada siklus ini terdapat beberapa hal yang harus di perbaiki, antara lain : guru mengarahkan kepada setiap kelompok agar lebih kompak dalam melakuakan Grup Investigation kemudian guru memeberikan sikap tegas pada masing-masing kelompok agar jangan hanya mengandalkan ketuanya dalam pelaksanaan kerja Tim. Adapaun hasil belajar siswa dalam siklus I dapat dirumuskan dalam grafik berikut:

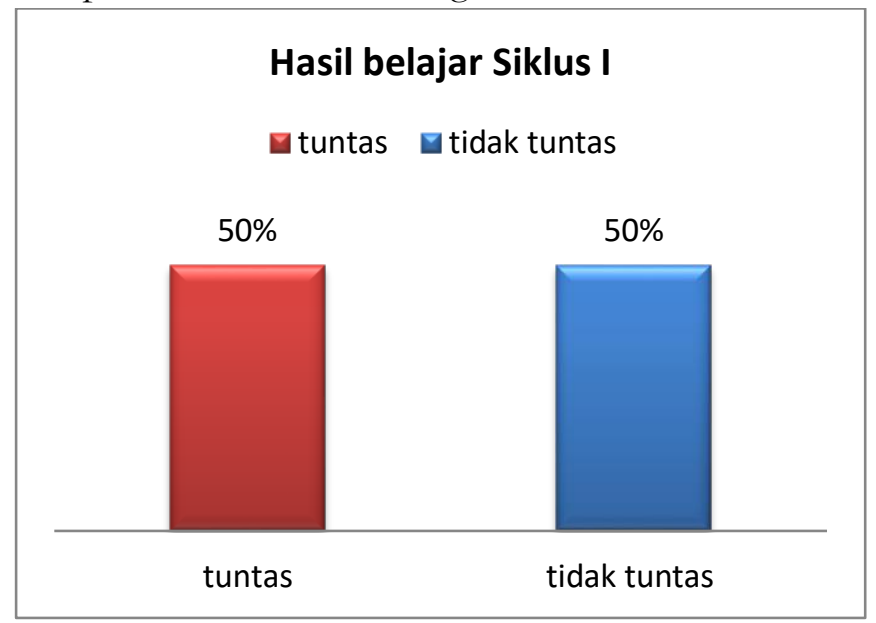

\section{Grafik 2. Persentase Hasil Belajar Siswa pada Siklus I}

Berdasarkan tabel dan grafik diatas dapat dianalisis sebagai berikut:

a. Pada pra tindakan yang telah mencapai kriteria keberhasilan yaitu baru 7 siswa (50 $\%$ ), yaitu nilai sama atau lebih dari KBM $73 \%$.

b. Pada pra tindakan terdapat 7 siswa (50\%) yang belum mencapai kriteria keberhasilan, yaitu nilai belum sesuai dengan KBM $73 \%$.

\section{Hasil Siklus II}

Pelaksanaan tindakan pada siklus II dilaksanakan pada hari hari Rabu, 3 November 2021, pukul 07:30 sampai 09:15 WITA (sebelum jam istirahat) dengan alokasi waktu $3 \mathrm{x}$ 35 menit, Sebelum melakukan tindakan peneliti terlebih dahulu mempersiapkan rencana pelaksanaan pembelajaran (RPP) dan Media Pembelajaran.

Pada akhir kegiatan siklus II diadakan refleksi proses pembelajaran yang telah dilakukan peneliti dan observer. Hasil refleksi pada siklus II ini menunjukkan bahwa 
peserta didik selama mengikuti pembelajaran Group Investigation sudah optimal sehingga hasil belajar matematika siswa kelas VB MI NW kalijaga meningkat. Penelitian tidak perlu melanjutkan ke siklus selanjutnya, karena hasil belajar siklus II sudah mencapai indikator keberhasilan. Hal ini tidak terlepas dari pemanfaatan media pembelajran PARIS ( Papan Ringkasan) yang sudah di buat oleh peneliti, proses pembelajaran lebih hidup dan memebuat mereka sanagat antusias. Adapaun hasil belajar siswa dalam siklus I dapat dirumuskan dalam grafik berikut:

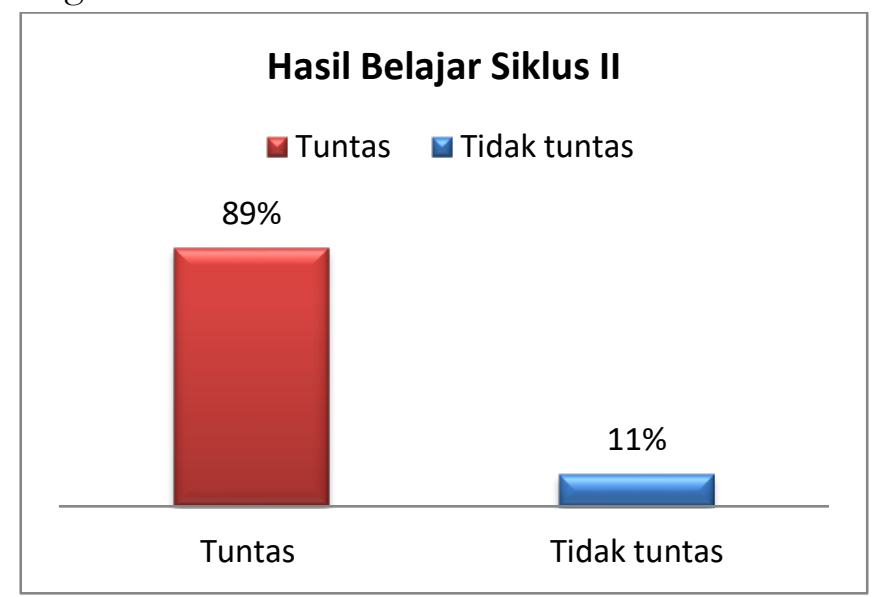

\section{Grafik 3. Persentase Hasil Belajar Siswa pada Siklus II}

Berdasarkan grafik di atas dapat dianalisis pada Siklus II yang telah mencapai kriteria keberhasilan yaitu 10 siswa (89\%), yaitu nilai sama atau lebih dari KBM 73\% dan terdapat empat siswa (11\%) yang belum mencapai kriteria keberhasilan, yaitu nilai belum sesuai dengan KBK 73\%. Hasil belajar Matematika pada siklus II mengalami peningkatan yang signifikan dibanding dengan siklus-siklus sebelumnya. Siswa yang mendapat nilai tinggi dapat mendominasi kriteria ketuntasan dan telah mencapai nilai standar KBM. Hal ini menandakan bahwa metode pembelajaran Model Cooperative Tipe Grup Investigation telah berhasil meningkatkan hasil belajar Matematika materi Kecepatan pada kelas VB semester 1 MI NW Kalijaga.Peningkatan hasil belajar kecepatan dapat dilihat pada tabel 2. dan tabel 3. berikut :

Tabel 2. Hasil Belajar Kondisi Awal Siklus I dan siklus II

\begin{tabular}{|c|c|c|c|c|}
\hline No & Rentang Nilai & $\begin{array}{c}\text { Kondisi } \\
\text { Awal }\end{array}$ & Siklus I & Siklus II \\
\hline 1 & $91-100$ & 0 & 2 & 5 \\
\hline 2 & $81-90$ & 1 & 3 & 2 \\
\hline 3 & $75-80$ & 4 & 2 & 3 \\
\hline 4 & $<75$ & 9 & 7 & 4 \\
\hline
\end{tabular}

Dari Tabel 2. menunjukkan bahwa pada kondisi awal atau pra siklus hanya ada lima siswa yang mengalami ketuntasan sesuai dengan KBM $(35,7 \%)$ kemudian meningkat menjadi tujuh siswa (50\%) pada siklus I dan meningkat signifikan menjadi 10 siswa (89\%) pada siklus II. 
Tabel 3. Hasil Belajar Kecepatan Kondisi Awal, Siklus I dan Siklus II

\begin{tabular}{|c|c|c|c|c|}
\hline No & Uraian & $\begin{array}{c}\text { Kondisi } \\
\text { Awal }\end{array}$ & Siklus I & Siklus II \\
\hline 1 & Nilai terendah & 30 & 30 & 40 \\
\hline 2 & Nilai tertinggi & 80 & 95 & 98 \\
\hline 3 & Nilai rata-rata & 56,8 & 63,2 & 75,6 \\
\hline 4 & Ketuntasan & $35,7 \%$ & $50 \%$ & $89 \%$ \\
\hline
\end{tabular}

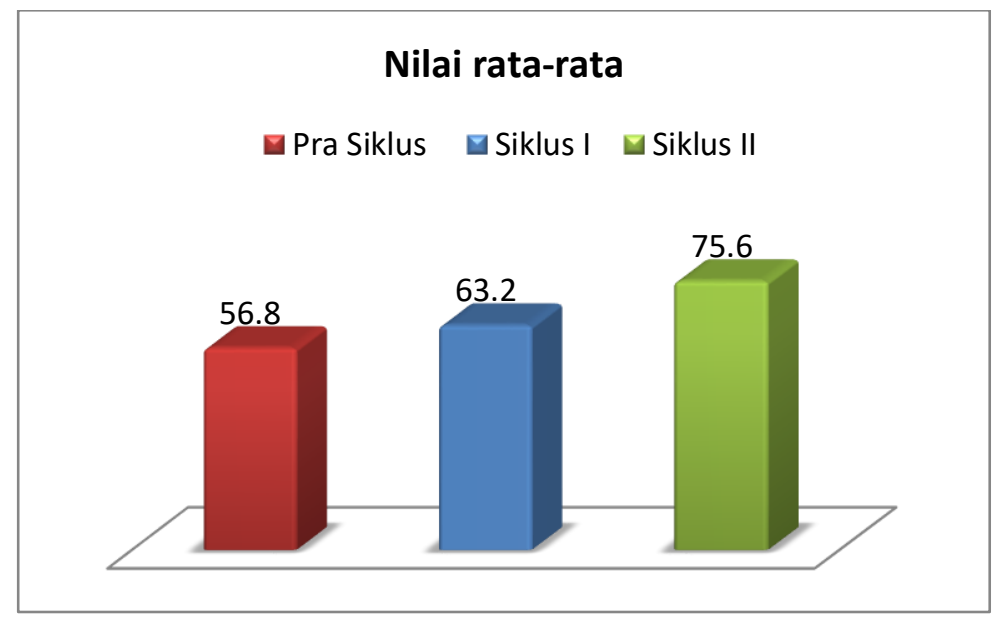

Grafik 4. Perbandingan Nilai Rata - Rata.

Berdasarkan tabel 3. dan Grafik 4. Diatas dapat dilihat bahwa dengan menggunakan model cooperative tipe Group Investigation dapat meningkatkan hasil belajar siswa materi kecepatan pada siswa kelas V B Semester I MI NW Kalijaga Tahun 2021. Hal ini dapat di lihat dari hasil belajar pada siklus I yang menunjukkan 50\% ketuntasan dengan nilai rata-rata 63,2 dibandingkan dengan kondisi prasiklus yaitu dengan ketuntasan 35,7\% dan nilai rata-rata 56,8 kemudian pada siklus II hasil belajar meningkat lebih signifikan yaitu dengan nilai ratarata 75,6 dengan kriteria ketuntasan 89\%.

Penggunaan media, alat peraga dan model pembelajaran yang tepat serta pemanfaatan lingkungan sekitar juga sangat sangat mempengaruhi hasil belajar. Hal ini akan menjadi sesuatu yang bermakna bagi siswa, karena siswa terlibat secara langsung, aktif mengikuti kegiatan, memberi pengalaman yang nyata dan konkret bagi siswa dalam pembelajaran sehingga pembelajaran menjadi bermakna, berkualitas, menyenangkan.

\section{Kesimpulan dan Saran}

Berdasarkan hasil penelitian tindakan kelas yang dilakukan melalui 2 siklus, dapat disimpulkan bahwa penggunaan model Group Investigation dapat meningkatkan hasil belajar materi kecepatan bagi siswa kelas VB MI NW Kalijaga.Pada kondisi awal atau pra siklus dari 14 siswa ketuntasan baru mencapai 35,7\% yaitu lima siswa tuntas KBM dengan nilai rata -rata 56,8, nilai tertinggi 93 dan nilai terendah 30.Dari kondisi awal tersebut setelah dilakukan perbaikan pembelajaran pada siklus I dari 14 siswa ada peningkatan menjadi tujuh siswa (50\%) yang tuntas KBM, nilai rata-rata 63,2, nilai tertinggi 95 dan nilai terendah 30. Pada perbaikan pembelajaran siklus II dari 14 siswa yang tuntas KBM meningkat lagi menjadi 10 siswa (89\%), nilai rata-rata 75,6 , nilai tertinggi 98 , nilai terendah 40 . 
Setelah penelitian tindakan kelas ini, peneliti mengemukakan saran-saran demi perbaikan penelitian, antara lain:

a. Guru perlu melakukan penelitian model pembelajaran yang beragam tentang mata pelajaran matematika agar siswa lebih tertarik, termotivasi, dan belajar terasa lebih menyenangkan.

b. Apabila akan dilaksanakan penelitian selanjutnya, perlu diungkap aspek yang lain, misalnya kemampuan siswa dalam model pembelajaran Group Investigation agar menjadi lebih aktif dalam pembelajaran materi apapun.

\section{Daftar Pustaka}

Cantik , Nimas laraswati (2019). Peningkatan Hasil Belajar Matematika Dengan Model Pembelaja Ran Group Investigation Pada Siswa Kelas III Sd Negeri 3 Kalikotes”. ( Klaten)

Joko, Iswahyudi, Suprayitno. Solichatun (2016) "Upaya Meningkatkan Hasil Belajar Matematika Menggunakan Model Group Investigation Materi Debit Air Siswa Kelas VI Zakariya SD Muhammadiyah Sukorejo Tahun 2016”. ISBN : 978-602-61599-6-0.

M. Munira (2017). Penerapan Model Pembelajaran Kooperatif Tipe Group Investigation (GI) dalam Meningkatkan Hasil Belajar Matematika Siswa Kelas XI IPA 2 SMA PMDS Putri Palopo. ( Palopo)

Slavin, E. Robert. 2005. Cooperative learning:Theory, research and practice. Londong:Allymand Bacon. Hlm 10

Saodih ,Nana Sukmadinata. 2017. Metode Penelitian Pendidikan, (Bandung: Remaja Rosdakarya,).

Subana, M.Strategi Belajar Mengajar Bahasa Indonesia, ( Bandung; Pustakan Setia)

Sutama. (2007). "Model Pembelajaran Kooperatif Tipe Group Investigation untuk Pengembangan Kreativitas Mahasiswa". Varidika/Vol. 19, No. 1, pp. 1-14.

Syahban Arham (2020), Pendidikan Jasmani dan Rohani, di akses di https://www.arhamsyahban.com/2020/04/ptk-pendidikan-jasmani.html pada hari rabu, 10 november 2021

Team pustaka phonix. 2008. Kamus Besar Bahasa Indonesia, (Cet. III; Jakarta: PT. Media Pustaka Phonix,).

Trianto. (2011). Model Pembelajaran Terpadu dalam Teori Dan Praktek. Jakarta: Prestasi Pustaka Publisher.

Widayanti , Anny. Penggunaan Metode Pembelajaran Group Investigation Untuk Pengajaran Matematika. Bangun Rekaprima Vol.05/1/April/2019. 